\title{
OPTIC DISC OEDEMA IN THE ABSENCE OF RAISED INTRACRANIAL PRESSURE*
}

\author{
BY \\ M. J. ROPER-HALL \\ Midland Centre for Neurosurgery, Birmingham
}

PAPILLOEDEMA is of particular interest to ophthalmologists and neurosurgeons. Its pathogenesis in raised intracranial pressure due to cerebral tumour is still argued-quite apart from its explanation in other conditions. Perhaps a study of those cases, admittedly rare, in which oedema of the optic discs occurs without raised cerebrospinal fluid pressure, and of cases without papilloedema in spite of raised cerebrospinal fluid pressure, will throw light on the main problem. It is the former type of case which I wish to discuss. I had originally entitled my paper "Papilloedema in the absence of raised intracranial pressure", but I am sure that the majority of those present would prefer to restrict the term "papilloedema" to cases with raised intracranial pressure, as defined by Parsons (1908) and Paton and Holmes (1911).

In none of the cases which I am presenting was there any loss of function, such as might be associated with optic neuritis, and the intracranial pressure was proved to be within normal limits by a lumbar puncture, after preliminary investigations had determined that such a procedure was safe to carry out.

When starting work at the Midland Centre for Neurosurgery I had certain ideas about the nature and significance of papilloedema. These ideas were shaken by finding cases with appearances closely simulating papilloedema from raised intracranial pressure, in which neurological and neurosurgical investigation was essentially negative, at least as an explanation of the oedema of the disc. Five typical cases are summarized in the Table (overleaf).

\section{Case Reports}

Case 1, a man aged 60, had experienced gradual weakness" of the left side of his body during the past 2 years and more recently difficulty with speech. He was very slow in all movements, to the extent of akinesia; he showed a slight weakness of the left arm and leg with increased reflexes, and a bilateral extensor plantar response. The systolic blood pressure varied between 170 and 200, and the diastolic blood pressure between 100 and $120 \mathrm{~mm}$. Hg. He showed bilateral disc oedema, with increased venous pressure, more marked on the right side. The retinal arterial pressures were $110+/ 55 \mathrm{~mm}$. Hg Right and $120+/ 55 \mathrm{~mm}$. Hg Left. Other relevant findings were an erythrocyte sedimentation rate of $26 \mathrm{~mm}$./hr; a skull $x$ ray showing some osteoporosis; bilateral carotid angiograms showing only arteriosclerotic cerebral vessels. At lumbar puncture, the initial pressure was $140 \mathrm{~mm}$. C.S.F., and the protein in the cerebrospinal fluid was $21 \mathrm{mg} . / 100 \mathrm{ml}$.

* Read at the combined meeting of the Society of British Neurological Surgeons and the 36th Annual Meeting of the Irish Ophthalmological Society in Dublin, May 16-18, 1957. 
TABLE

SUMMARY OF

\begin{tabular}{|c|c|c|c|c|c|c|}
\hline \multirow{2}{*}{ Case No. } & \multirow{2}{*}{ Sex } & \multirow{2}{*}{ Age (yrs) } & \multirow{2}{*}{ Disc Appearance } & \multicolumn{2}{|c|}{ Corrected Visual Acuity } & \multirow{2}{*}{$\begin{array}{c}\text { Visual Fields* } \\
\text { Blind Spots }\end{array}$} \\
\hline & & & & Right & Left & \\
\hline 1 & $\mathbf{M}$ & 60 & $\begin{array}{l}\text { Papilloedema } \\
\text { right }>\text { left } \\
\text { Vein pressure up }\end{array}$ & $6 / 5$ & $6 / 6$ & 一 \\
\hline 2 & $\mathbf{M}$ & 66 & $\begin{array}{l}\text { Papilloedema right } \\
\text { and left } \\
\text { Later: Veins engorged } \\
\text { right partial } \\
\text { obstruction }\end{array}$ & $6 / 9$ & $6 / 6$ & Enlarged \\
\hline 3 & $\mathbf{M}$ & 30 & $\begin{array}{l}\text { Papilloedema right } \\
\text { and left } \\
\text { Later: Right oedema } \\
\text { and vein engorged } \\
\text { left normal }\end{array}$ & $6 / 12$ & $6 / 5$ & Right Enlarged \\
\hline 4 & $\mathbf{F}$ & 27 & $\begin{array}{l}\text { Papilloedema right } \\
\text { and left } \\
\text { Vein pressure } \\
\text { response normal }\end{array}$ & $6 / 9$ & $6 / 18$ & $\begin{array}{l}\text { Both enlarged } \\
\text { with central } \\
\text { spread left }\end{array}$ \\
\hline 5 & $\mathbf{F}$ & 48 & $\begin{array}{l}\text { Old Papilloedema } \\
\text { right } \\
\text { Left vein engorged } \\
\text { with glia }\end{array}$ & $6 / 6(-4)$ & $6 / 6(-1)$ & Right enlarged \\
\hline
\end{tabular}

* Fields all

The relatively high retinal arterial pressure as compared with the systemic blood pressure, as well as the other findings, were those of hypertension passing into a malignant phase, with papilloedema and normal cerebrospinal fluid pressure.

Case 2, a man aged 66, had been diagnosed as a case of bilateral papilloedema by an ophthalmologist and a neurologist. He was admitted to hospital some weeks later, and when he was seen on February 23, 1956, the findings were less strikingly those of papilloedema and could better be described as bilateral venous engorgement, with partial obstruction of the right central retinal vein. The visual acuity was $6 / 9$ in the right eye with glasses and $6 / 6$ in the left eye with glasses. The visual fields were full peripherally, with enlargement of the blind spots. The pressure in the central retinal vein on the right side was $48 \mathrm{~mm}$. $\mathrm{Hg}$ and on the left $20 \mathrm{~mm}$. Hg. The ocular tension in the right eye was raised to 35 and in the left to $28 \mathrm{~mm}$. $\mathrm{Hg}$ (Schiötz). At lumbar puncture the initial pressure was $100 \mathrm{~mm}$. cerebrospinal fluid. The blood pressure was $155 / 110$.

A few months after his return home, he was taken acutely ill with severe abdominal pain and died 2 days later on 29.9.56. A post-mortem examination showed haemoperi- 
FIVE CASES

\begin{tabular}{|c|c|c|c|c|c|}
\hline \multicolumn{2}{|c|}{ Dynamometry } & \multirow{2}{*}{$\begin{array}{l}\text { Blood } \\
\text { Pressure } \\
\text { (mm. Hg) }\end{array}$} & \multirow{2}{*}{$\begin{array}{l}\text { Lumbar } \\
\text { Puncture } \\
\text { (Initial } \\
\text { pressure } \\
\text { mm.C.S.F.) }\end{array}$} & \multirow{2}{*}{ Remarks } & \multirow{2}{*}{ Investigations } \\
\hline Right & Left & & & & \\
\hline$\underset{110+/ 55}{\text { Art }}$ & $\stackrel{\text { ial }}{120+/ 50}$ & $170 / 100$ & 140 & $\begin{array}{l}\text { Akinesia } \\
\text { Left spastic } \\
\text { hemiparesis } \\
\text { Plantars } \uparrow \uparrow\end{array}$ & $\begin{array}{l}\text { E.S.R. } 26 \mathrm{~mm} . / \mathrm{hr} . \\
\text { Skull osteoporosis } \\
\text { Angiogram arteriosclerosis } \\
\text { C.S.F. protein } 21 \mathrm{mg} \text {. per } \\
100 \mathrm{ml} .\end{array}$ \\
\hline $48^{\mathrm{Ve}}$ & ous 20 & $155 / 110$ & 100 & $\begin{array}{l}\text { Died 29.9.56 } \\
\text { Dissecting } \\
\text { aortic } \\
\text { aneurysm }\end{array}$ & $\begin{array}{l}\text { Ocular tension (mm. Hg } \\
\text { Schiötz) right } 35 \text {, left } 28 \\
\text { X-ray chest and skull, right } \\
\text { carotid angiogram normal } \\
\text { C.S.F. protein and cells } \\
\text { slight increase }\end{array}$ \\
\hline $\begin{array}{c}100 \\
\text { Art } \\
110 / 60\end{array}$ & $\mathrm{rial}_{100 / 40}^{-}$ & $130 / 80$ & 210 & - & - \\
\hline $90 / 40$ & $85 / 40$ & $130 / 80$ & 160 & $\begin{array}{l}\text { Later: Right } \\
\text { disc normal } \\
\text { left disc } \\
\text { almost normal }\end{array}$ & $\begin{array}{l}\text { C.S.F. protein-normal } \\
\text { Cells-slight increase }\end{array}$ \\
\hline $120 / 50$ & $130 / 50$ & $145 / 80$ & 110 & 一 & $\begin{array}{l}\text { X-ray chest and skull, left } \\
\text { carotid angiogram normal } \\
\text { Right carotid angiogram } \\
\text { showed aneurysm of } \\
\text { post-communicating } \\
\text { artery }\end{array}$ \\
\hline
\end{tabular}

full peripherally.

toneum due to the rupture of a dissecting aneurysm of the abdominal aorta.

Case 3, a man aged 30, was referred as a case of bilateral papilloedema by an ophthalmologist, an opinion which was supported by a neurosurgeon. Clinical examination was negative, apart from the ophthalmic findings. The blood pressure was 130/80. Chest and skull $x$ rays and a right carotid angiogram were normal. The cerebrospinal fluid showed a slight increase in protein and cells. Other investigations were negative.

As in Case 2, when the patient was admitted to hospital, the eye findings were less convincing, there was oedema localized to the right optic disc, with marked venous engorgement; the appearance of the left disc was now within normal limits. Visual acuity with correction was $6 / 12$ in the right eye, and $6 / 5$ in the left. The visual fields were full peripherally, showing an enlarged blind spot on the right side, the left being normal. The pressure in the right central retinal vein was raised to $100 \mathrm{~mm}$. Hg. The left central retinal vein collapsed immediately on pressure on the globe. The right central retinal artery had a pressure of $110 / 60$ and the left $100 / 40$. At lumbar puncture the initial pressure was $210 \mathrm{~mm}$. cerebrospinal fluid. 
Cases 2 and 3 are examples of difficulty in the differential diagnosis between partial obstruction of the central retinal vein and papilloedema. Both cases show venous pressures which are sufficient to embarrass the nutrition in the region of the optic disc.

Case 4, a woman aged 27, gave a history of two attacks of headache and loss of vision, one year ago and 10 days ago, each lasting for only a short time. She was found, on examination, to have bilateral papilloedema. When seen on November 17, 1956, she still showed bilateral papilloedema, but with a normal venous pressure response; the retinal arterial pressures were $90 / 40$ in the right eye and $85 / 40$ in the left eye. The visual acuity in the right eye was $6 / 9$ and in the left $6 / 18$, with no refractive error. The visual fields showed normal peripheral isopters and enlarged blind spots with central extension towards the fixation point in the left eye. From these appearances, it seemed that the cerebrospinal fluid pressure might be normal, and at lumbar puncture the initial pressure was found to be $160 \mathrm{~mm}$. C.S.F. The cerebrospinal fluid showed a slightly raised cell count, but normal protein. 2 months later (on January 1, 1957) this patient was reported to have a normal appearance of the right disc and an almost normal left disc.

It seems likely that this patient had suffered a transient rise of intracranial pressure and was admitted for investigation with oedema of the discs remaining after the cerebrospinal fluid pressure had returned to normal, as one would expect to see in benign intracranial hypertension.

Case 5, a woman aged 48, gave a history of blurring of vision in the right eye with orbital swelling. On examination in October, 1956, she was found to have right papilloedema and left venous engorgement, with glial tissue on the disc. The visual fields showed no defect on perimetry or screening. The retinal arterial pressures were $110+/ 50$ in each eye, and the blood pressure was $145 / 80$. The urine showed no abnormality. On February 28,1957 , the ophthalmic findings were those of old-standing papilloedema in the right eye with venous engorgement but normal pressure response; the left eye showed venous engorgement and gliosis, as previously described. The arterial diastolic pressures in the retina were 50 in the right eye and $\mathbf{4 5}$ in the left. The visual acuity in the right eye was $6 / 6(-4)$ and in the left eye $6 / 6(-1)$, with correction. The visual fields showed a full periphery, with slight contraction of the central isopters in the right eye and an enlarged blind spot. Neurological examination was otherwise negative. At lumbar puncture the initial pressure was $110 \mathrm{~mm}$. C.S.F. Chest and skull $x$ rays and left angiogram were normal. The right angiogram showed an aneurysm of the right posterior communicating artery.

The finding of an aneurysm in this situation was quite unexpected and difficult to relate directly to the optic disc oedema. It might lend support to the suggestion of a vaso-motor cause for the oedema of the disc, which is also supported by the high retinal arterial pressure relative to the brachial pressures.

\section{Summary of Cases}

(1) The first was a case of a hypertension passing into a malignant phase.

(2) and (3) The second and third cases were examples of incomplete central vein obstruction.

(4) The fourth was a case of papilloedema, first seen in a regressive phase.

(5) The fifth case showed a relative hypertension of cerebral circulation, with an aneurysm on the circle of Willis. 
All the patients had normal cerebrospinal fluid pressures and, apart from Case 4 with probable benign intracranial hypertension in the regressive phase, they had local vascular conditions of the optic discs, produced in different ways but in each case comparable to those which occur in raised intracranial pressure.

These cases were admitted to the Midland Centre for Neurosurgery during a period when six hundred cases were admitted for intracranial conditions, eleven of these being classified as benign intracranial hypertension.

\section{Previous Reports of Cases}

One finds a great many articles entitled: "Papilloedema in a case of so-andso", which would usually be better entitled: "Raised cerebrospinal fluid pressure in a case of so-and-so", because the histories reveal that the cerebrospinal fluid pressure was in fact raised (Watkins, Wagener, and Brown, 1941; Masson, Durix, and Perrin, 1950; Vissi and Dobrina, 1950; Devanney and Shea, 1952).

It is also clear that the term papilloedema is often used loosely to describe cases where there is considerable loss of vision or extensive field defect (Wilson and Darkes, 1933; Chamlin and Davidoff, 1950; McPherson, 1955).

It seems that in optic disc oedema associated with blood dyscrasias the cerebrospinal fluid pressure has been found to be raised whenever it has been checked, but it is conceivable that in such cases oedema might be brought about by anoxia (Watkins, Wagener, and Brown, 1941).

In hypoparathyroidism, papilloedema, when it occurs, is always associated with cerebral oedema, and in all cases where the cerebrospinal fluid pressure was measured it was found to be raised (Walsh and Murray, 1953).

Normal or low cerebrospinal fluid pressures have been recorded with disc oedema in cases of malignant hypertension, in the Guillain-Barré syndrome of polyradiculitis with high cerebrospinal fluid protein levels, and in traumatic hypotension. Mention should also be made of simulated bilateral papilloedema in association with drusen of the optic nerve.

In studying malignant hypertension, Taylor, Corcoran, and Page (1954) take the upper limit of normal cerebrospinal fluid pressure to be $250 \mathrm{~mm}$., which I think will be considered a little high. However, taking this as the standard highest level, there were 100 patients who had disc oedema and 57 of these were found to have cerebrospinal fluid pressures below $250 \mathrm{~mm}$. Taylor and others (1954) conclude that the association between cerebrospinal fluid pressure and disc oedema in the presence of hypertension is collateral rather than causal. The disc oedema was not associated with any evident increase in brain volume. Fishberg and Oppenheimer (1930) reached similar conclusions.

With regard to the Guillain-Barré syndrome, Drew and Magee (1951) found a total of ten cases in the literature, four of which had a low cerebrospinal fluid pressure. In their own case, there was a pressure of $150 \mathrm{~mm}$. C.S.F. or less at lumbar puncture on four occasions-but 6 weeks after the onset of the disease the pressure was raised to $250 \mathrm{~mm}$.

Studying ventricular hypotension, Sadoughi (1950) reported observations of cases with optic disc oedema, in which there had been no symptoms suggesting a previous hypertensive phase and the disc oedema appeared to be associated with cerebral oedema. He concluded that cerebral oedema can give rise to an oedema 
of the disc, which is most frequently associated with a raised cerebrospinal fluid pressure but can be associated with a low pressure.

Discussing drusen of the optic nerve, Lyle (1953) mentioned a case which was thought to show bilateral papilloedema of moderate degree and was admitted to a neurosurgical hospital to be thoroughly investigated. The visual acuity and visual fields were normal and no abnormality was found after investigation. Chamlin and Davidoff (1950) describe cases in which nerve fibre bundle defects are shown on visual fields and serve to differentiate the condition from true papilloedema. However, Chamlin and Davidoff (1952) state that enlarged blind spots and peripheral contraction may cause the condition to resemble papilloedema very closely. Case 7 in an article on bilateral papilloedema by Abrahamson, Retter, and LaFia (1953) was that of a patient who showed drusen bodies on the right disc; in spite of this, these authors felt that the oedema which they saw was true papilloedema, because, after ventriculography, the enlarged blind spots became smaller, the patient's symptoms of headache improved, and the papilloedema subsided.

Thiébaut and Matavulj (1955) described a case of encephalitis in which hypotension was discovered at ventricular puncture. This patient had previously been given hypertonic serum to relieve her headaches. After ventricular puncture, the patient was rehydrated and then the papilloedema appeared; it therefore seems possible that the cerebrospinal fluid pressure was also raised at this time, although no estimation of the pressure was made.

\section{Discussion}

On considering the cases which I have reported and those taken from the literature, it is clear that in some conditions-namely, in partial retinal vein obstruction, in malignant hypertension, in the Guillain-Barré syndrome, and in hypotension after cranial trauma-oedema of the optic discs has been observed without a raised cerebrospinal fluid pressure. Hence, compression of the central vein as it passes across the sub-arachnoid space can be ruled out as a factor in the production of the oedema in these cases. Before discussing the manner of its production in these cases, certain facts should be noted:

Cannon (1901) pointed out that, in circumstances of non-nutrition, the brain will take up water from a solution isotonic with blood and will thereby exert pressure sufficient to exclude the blood from the cerebral vessels.

Samuels (1938) pointed out that a post-mortem swelling of the papilla is not unusual, and an inexperienced examiner might be induced to make a diagnosis of choked disc.

Van Heuven and Fischer $(1936,1937)$ showed that the brain has a water-binding capacity comparable to that of a true gel, a property shared by the optic nerve. The retina, on the contrary, swells to a much less extent; and this appears to me to be a much more satisfactory explanation of the limitation of papilloedema to the neighbourhood of the nerve head than that given by Lyle (1953), who says it is due to the firm attachment of the footplates of the fibres of Müller at the disc edge.

It seems to me that if the arterial supply to the optic nerve is cut off suddenly a complete loss of vision will result, but if it is sufficiently gradual 
the reduction of nutrition and anoxia may lead to oedema without loss of function. This is a condition which may be seen in malignant hypertension. In papilloedema due to raised intracranial pressure, similar circumstances of impaired nutrition may arise at a lower arterial pressure when this is coupled with embarrassment of venous return. Finally, a similar reduction in nutrition may take place with a higher rise of venous pressure due to partial venous obstruction.

My suggestions are supported by the findings of Bailliart (1929), Sobański (1937), and Redslob (1950) that in raised intracranial tension without papilloedema the retinal arterial diastolic pressure is always found to be raised and drops rapidly on reduction of intracranial pressure. On the contrary, the retinal arterial pressure is found to fall with the appearance of papilloedema-in other words, the elevation of retinal arterial pressure is an adaptation to the intracranial pressure, and when the diastolic pressure cannot keep pace with the rise of intracranial pressure papilloedema results. A similar state of affairs in the cerebral vessels could be expected to cause cerebral oedema.

In addition, the normal ratio of arterial to venous pressure in the retina is said to be 3:1, and if this relationship holds oedema does not occur; but if the relationship reaches $3: 2$ oedema occurs, because the arterial pressure is insufficient to maintain an adequate capillary circulation. Support to this theory is also given by Brégeat (1956), who concluded that if papilloedema occurred in the presence of low intracranial pressure there could be no other explanation except that of vaso-motor phenomena in the optic nerve head.

\section{Conclusion}

It would appear that the type of case which I have been discussing will be encountered more frequently in the future as a result of modern methods of neurosurgical investigation. Lumbar puncture, which a few years ago might have been done as an early diagnostic procedure in such cases, will now not be done for fear of causing a pressure cone. I would suggest, however, that, after precautionary investigations (such as ventriculography) have proved negative, lumbar puncture should be carried out, because the impressions at ventriculography can be inaccurate in judging the intracranial pressure; in just the same way it is often difficult for the ophthalmologist to obtain an accurate impression of the intra-ocular pressure by palpation, the tonometric readings being frequently unexpected.

Recordings of the venous and arterial diastolic pressure at the optic disc could well be made part of the routine examination in patients with optic disc oedema or suspected to have raised intracranial pressure. This would allow direct comparison with the cerebrospinal fluid and systemic blood pressures. In an individual case it may not be of much value to take a single group of measurements which could give a misleading impression when phasic variations are taking place. 


\section{Summary}

Cases of optic disc oedema associated with normal intracranial pressure, seen personally, are correlated with other reported cases. The suggestion is put forward that, by a simple alteration of the arterial and venous pressure ratios at the optic disc, papilloedema can be accurately simulated-lending support to the theories which suggest similar conditions in the aetiology of true papilloedema.

I should like to express my gratitude to my colleagues at the Midland Centre for Neurosurgery for their ready cooperation.

\section{ADDENDUM}

It was interesting to notice, on examination of the four cases shown this morning of drusen bodies in the optic nerve, that in three instances the venous pressure at the optic nerve head was raised while in the fourth it was normal: and in the three cases with raised venous pressure, the drusen were not especially notable on the disc head but appeared to be much deeper, whereas, in the case without raised venous pressure, the drusen were mostly superficially placed.

\section{REFERENCES}

Abrahamson, I. A., Retter, R., and LaFia, D. (1953). U.S. armed Forces med. J., 4, 1093.

BaIlliart, P. (1929). Ann. Oculist. (Paris), 166, 271-295.

BrÉgeat, P. (1956). “L'Oedème papillaire." Rapport présenté à la Société française d'ophtalmologie. Masson, Paris.

Cannon, W. B. (1901). Amer. J. Physiol., 6, 91.

Chamlin, M., and Davidoff, L. M. (1950). J. Neurosurg., 7, 70. (1952). Amer. J. Ophthal., 35, 1599.

Devanney, J. W., and Shea, J. H. (1952). A. M. A. Arch. Neurol. Psychiat., 68, 791.

DREW, A. L., and MAGEe, K. R. (1951). Ibid., 66, 744.

Duke-EldER, S. (1940). "Text-book of Ophthalmology", vol. 3, pp. 2944-2960. Kimpton, London.

Fishberg, A. M., and OPPENHeImer, B. S. (1930). Arch. intern. Med., 46, 901.

LYLE, T. K. (1953). Trans. ophthal. Soc. U.K., 73, 87.

MCPherson, S. D. (1955). Amer. J. Ophthal., 39, 294.

Masson, R., Durix, C., and Perrin, A. (1950). Lyon méd., 184, 161.

Parsons, J. H. (1908). "The Pathology of the Eye", vol. 4, p. 1349. Frowde and Hodder and Stoughton, London.

Paton, L., and Holmes, G. (1911). Trans. ophthal. Soc. U.K., 31, 117.

REDSLOB, E. (1950). Rev. Oto-neuro-ophtal., 22, 1.

SAdoughi, G. (1950). Bull. Soc. Ophtal. Fr., 1, 17.

SAmuels, B. (1938). Trans. ophthal. Soc. U.K., 57, (Pt. II), 529.

SobAŃsKI, J. (1937). v. Graefes Arch. Ophthal., 137, 84.

Taylor, R. D., Corcoran, A. C., and Page, I. H. (1954). Arch. intern. Med., 93, 818.

Thiébaut, F., and Matavulu, N. (1955). Arch. Ophtal. (Paris), 15, 813.

VAN Heuven, J. A., and Fischer, P. F. (1936). Brit. J. Ophthal., 20, 204. (1937). Ibid., 21, 352.

VisSi, F., and Dobrina, D. (1950). Riv. oto-neuro-oftal., 25, 437.

WALSh, F. B., and MurRay, R. G. (1953). Amer. J. Ophthal., 36, 1657.

WATkIns, C. H., WAGener, H. P., and Brown, R. W. (1941). Ibid., 24, 1374.

Wirson, G., and Darkes, W. F. (1933). J. Amer. med. Ass., 100, 1233. 